Article

\title{
Disaster Governance in Conflict-Affected Authoritarian Contexts: The Cases of Ethiopia, Myanmar, and Zimbabwe
}

\author{
Isabelle Desportes * and Dorothea Hilhorst \\ International Institute of Social Studies, Erasmus University Rotterdam, 20502 LT The Hague, The Netherlands; \\ E-Mails: desportes@iss.nl (I.D.), hilhorst@iss.nl (D.H.) \\ * Corresponding author
}

Submitted: 15 April 2020 | Accepted: 27 June 2020 | Published: 10 December 2020

\begin{abstract}
Disaster governance in conflict areas is of growing academic concern, but most existing research comprises either single case studies or studies of a variety of country contexts that group all types of conflict together. Based on three case studies, this article offers a middle-ground scenario-based approach, focusing on disaster governance in authoritarian contexts experiencing low-intensity conflict. Low-intensity conflict is characterized by intense political tensions and violence that is more readily expressed in ways other than direct physical harm. Inspired by Olson's (2000) maxim that disasters are intrinsically political, this article explores the politics of disaster response by asking what is at stake and what happened, unpacking these questions for state, civil society, and international humanitarian actors. Using data from a total of one year of qualitative fieldwork, the article analyzes disaster governance in 2016 drought-ridden Ethiopia, marked by protests and a State of Emergency; 2015 flooded Myanmar, characterized by explosive identity politics; and 2016-2019 drought-ridden Zimbabwe, with its intense socioeconomic and political turbulence. The study's findings show how framing and power processes in disaster governance-comprising state and non-state actors-largely lean toward the state, with the consequence that political interests, rather than needs assessments, steer who and what will be protected from disaster impact.
\end{abstract}

\section{Keywords}

authoritarianism; conflict; disaster response; Ethiopia; governance; humanitarian; Myanmar; politics; Zimbabwe

\section{Issue}

This article is part of the issue "The Politics of Disaster Governance" edited by Dorothea Hilhorst (Erasmus University Rotterdam, The Netherlands), Kees Boersma (Vrije Universiteit Amsterdam, The Netherlands) and Emmanuel Raju (University of Copenhagen, Denmark).

(C) 2020 by the authors; licensee Cogitatio (Lisbon, Portugal). This article is licensed under a Creative Commons Attribution 4.0 International License (CC BY).

\section{Introduction}

In 2000, Olson asked, "Why has it been so difficult to gain sustained, systematic attention to the political aspects of disasters?" (2000, p. 265). The question is still being asked today, with a particularly strong call to study micropolitical dynamics in situations where disaster and conflict overlap (Peters, Holloway, \& Peters, 2019; Siddiqi, 2018). Disaster governance-the interplay of different actors reducing and/or responding to disaster risks-is beset by politics. This is especially the case in conflictaffected areas, where the response parameters differ vastly from the disaster response mechanisms specified in, for example, the Sendai Framework for Action (United Nations International Strategy for Disaster Reduction, 2015). Moreover, the existing disaster-conflict literature rarely recognizes the diversity of conflict situations. This article therefore focuses on one type of conflict-lowintensity conflict (LIC) in authoritarian settings.

Despite constituting the largest share of conflicts worldwide, LICs are generally under-researched (Heidelberg Institute for International Conflict Research, 2019). In LIC settings, violence is more readily expressed in ways other than direct physical harm. Largely unpredictable riots, violent clashes, targeted attacks, and repression are indeed part of the conflict, but scholars 
foreground accusatory rhetoric, discriminatory policies, and other forms of structural and cultural violence, which fuel tensions within and across state and societal groups (Azar, 1990; Demmers, 2012; Galtung, 1996). LICs are generally associated with a threshold of fewer than 1,000 casualties and are not unique to authoritarian settings (Human Security Report Project, 2016). Authoritarian practices also differ from illiberal practices (i.e., human rights infringements) in that they specifically pose a threat to democratic processes. Through authoritarian practices, accountability between people and their political representatives is sabotaged "by means of secrecy, disinformation and disabling voice" (Glasius, 2018 , p. 517). However, authoritarian and illiberal practices often go hand in hand, especially in protracted conflict situations with cycles of contestation and repression (Azar, 1990).

In authoritarian LICs, an important disaster response parameter is the complex nature of the state, which tends to be functioning but repressive. Understanding of humanitarian-state interactions in settings where the state constitutes a "hazard" for precarious communities remains limited (Carrigan, 2015, p. 121). This lack of understanding is particularly problematic because current international and (most) national disaster policy identifies the state as the primary disaster response actor and interlocutor for civil society and international humanitarian actors (Harvey, 2013).

There are two dominant strands in existing conflictdisaster research. The first is single case studies, where the description of specific path dependencies and processes limit the theoretical understanding of broader institutional processes at play (e.g., de Billon \& Waizenegger, 2007; Venugopal \& Yasir, 2017). The other strand grounds its claims in large- $\mathrm{N}$ studies grouping together dozens of 'conflict' country cases (e.g., Drury \& Olson, 1998; Nel \& Righarts, 2008). Research in this second strand has focused on establishing macrolevel causal linkages between disasters, conflict, and peace, without seeking in-depth understanding of the processes through which conflict affects societies' ability to respond to disasters, weakens institutional response capacity, and hampers the provision of aid (Wisner, 2012). This article takes an intermediate approach between the two existing research strands, discussing three authoritarian LIC cases. This work is part of a series of small-N studies, which also draws out disaster-conflict dynamics in high-intensity and post-conflict scenarios (Hilhorst, van Voorst, Mena, Desportes, \& Melis, 2019). We rely on scenario-building to describe core political processes that are ideal-typical of a particular type of conflict.

The present article draws on one year of qualitative fieldwork in Ethiopia (focusing on the 2016 drought overlapping with protests and a State of Emergency), Myanmar (focusing on the 2015 Cyclone Komen response and explosive identity politics), and Zimbabwe (focusing on the 2016-2019 drought coinciding with intense socioeconomic and political turbu- lences). A first phase of analysis described the uniqueness of the individual cases in three separate publications on Ethiopia (Desportes, Mandefro, \& Hilhorst, 2019), Myanmar (Desportes, 2019), and Zimbabwe (Desportes, 2020). This article presents the results of the second phase of analysis, where the different contexts were brought "together and into the same analytical frame," allowing us to "think with insights from elsewhere" (Robinson, 2016, p. 193-194). At this stage, we aimed to bring all three cases into conversation with each other (Jacobs, 2012), seeking contrasts and similarities between them to advance the conceptualization of disaster-conflict dynamics in authoritarian LIC areas.

\section{Disaster Politics in Authoritarian Low-Intensity Conflict Settings}

The largely technocratic nature of disaster studies has been challenged since the 1980s, with the introduction of the 'vulnerability paradigm' (Blaikie, Cannon, Davis, \& Wisner, 1994; Hewitt, 1983; O’Keefe, Westgate, \& Wisner, 1976; Wisner, Blaikie, Cannon, \& Davis., 2003). This school of thought highlighted how political, economic, and social processes produce vulnerabilities that turn hazardous events into disasters. Although this body of work certainly recognized the importance of political processes in the creation of disaster risks, Olson's (2000) article "Toward a Politics of Disaster: Losses, Values, Agendas and Blame" was seminal in setting a research agenda for how politics works during and in the aftermath of disaster. Olson called for scholars to approach disasters as explicitly political processes, highlighting how, in addition to being managed through authorities taking certain actions instead of others and allocating resources (and thus values) in specific ways, disasters must also be explained. Olson put forward three questions which are commonly debated by political representatives and societal actors, thus turning disasters into "agenda control and accountability crises" (Olson, 2000, pp. 266, 273):

1. What happened? (This entails defining the meaning of the event and inscribing it within causal stories about why the disaster happened and what its consequences are).

2. Why were the losses (so) high and/or the response (so) inadequate? (This is what Olson refers to as the 'blame game' of assigning responsibility).

3. What will happen now? (This question is about determining how resources are allocated for recovery and reconstruction efforts).

We take inspiration from Olson's questions, modifying them to reflect current notions about disaster governance. We also adapt them to our study's focus, i.e., select the questions which can best draw out the political dynamics that are key to disaster response in authoritarian LIC settings. 
Our focus on disaster response specifically, excluding recovery and reconstruction, positions question three outside the scope of our study. Moreover, although Olson was mainly interested in the role of "authorities, governments and entire regimes" (Olson, 2000, p. 283), more recent disaster governance literature highlights how disaster response results from interactions between the state, civil society, humanitarians, and a variety of other actors. These interactions take place in a humanitarian arena in which multi-level power relations play a major role (Hilhorst \& Jansen, 2010). The question of 'what happened' should therefore be unpacked for different groups of actors who bring their own frames and interests to the table to shape the disaster response process and who draw on different sources of power to advance their views and interests.

Paying attention to the interplay between different actors is especially important because power is inherently relational and performative (Giddens, 1984, pp. 257-258). Authoritarian LIC scenarios are marked by significant power imbalances that emerge through interactions between state and non-state actors: The state holds 'naturalized authority' and coercive power to allocate resources and restrict non-state actors (del Valle \& Healy, 2013; Desportes et al., 2019, p. 36). Some international actors such as donor agencies rely on 'soft' (financial) power to influence the humanitarian space, they can thus also act as authorities allocating resources and values. But international actors are often perceived as external actors interfering with or even threatening the internal domestic order (Cunningham, 2018, p. 31). It is crucial to distinguish between state and non-state actors when analyzing disaster response, but it is also important to take into account that some non-state actors do have power and can act as 'authorities.' This actor differentiation is reflected in our analysis and in the questions explored in this article.

We also refine Olson's attention to politics by bringing 'everyday politics' more explicitly into the picture. Everyday politics determine the control, allocation, production, and use of resources, as well as the values and ideas underlying activities. Everyday politics play a key role in shaping disaster response interactions in practice (Hilhorst, 2013). In relation to disasters, being cognizant of everyday politics implies scrutinizing the 'normal' acts of disaster response: "The selection of risks to be addressed, the allocation of burdens generated by particular risks, the intentions and interactions of different actors and the choices to apply certain techniques over others" (Hilhorst, 2013, p. 2). Olson's questions mostly refer to 'big political framings,' political stakes, values, and accusations. Generating more detailed questions helps in capturing disaster responders' socially embedded everyday interactions.

In this article, we thus examine the following three questions. The first, what is at stake? Disaster response evolves around more than alleviating suffering. Disasters "open political space for the contestation or concentra- tion of political power and the underlying distributions of rights between citizens and citizens and the state" (Pelling \& Dill, 2010, p. 15). Emphasizing the 'disaster as lens' over the 'disaster as catalyst' approach, some scholars have stressed that disasters reveal rather than disrupt social struggles and inherent inequities (Cuny, 1983), relationships between actors (Pelling \& Dill, 2006), and political narratives (Venugopal \& Yasir, 2017). This is particularly true in LIC settings, where political power and the distribution of rights are already contested before the disaster and where emotions and accusations often override facts that are difficult to assess (Desportes et al., 2019; Hutchison, 2014). Referring again to Olson (2000), disaster responders may gain or lose in legitimacy and power because of their actions but also because of how their actions and motivations are framed or 'explained.'

Second, what will happen now from the authorities' side? Literature on LIC and authoritarian dynamics directs our attention to the structural and cultural means through which power and violence are expressed (Galtung, 1996). Everyday politics are central in that legal instruments, bureaucracy, and daily engagements with government officials or community leaders restrict or influence aid access, activities, and beneficiary selection (Desportes, 2019; Hilhorst, 2013). Authoritarian modes of control involve establishing restrictions but also instilling a culture of uncertainty and fear (Glasius et al., 2018).

The third and final question concerns what will happen now from the non-authorities' side. For non-state actors facing restrictions in authoritarian LIC settings, outspoken confrontation is rarely the preferred option (Cunningham, 2018). A more common strategy is socially navigating around challenges-adjusting and interacting with a constantly moving social environment, with specific tactics depending on the situation (Vigh, 2009). In what has been termed the 'governance of perceptions,' disaster responders operating in authoritarian LIC settings seek to balance the expectations of various groups (Desportes, 2019, p. 13), including by presenting themselves as respecting state sovereignty while still being seen as fair by aid recipient communities.

\section{Three Similar Disaster-Conflict Country Cases}

In 2016 in Ethiopia, in 2015 in Myanmar, and in 2016-2019 in Zimbabwe, a disaster unfolded against the backdrop of ongoing authoritarian practices and LIC rooted in deep-seated dissatisfaction with the regime in power (see Markakis, 2011, on Ethiopia; Matelski, 2016, on Myanmar; and McGregor, 2013, on Zimbabwe). In all three countries, protests met with violence and repression occurred or were reignited following a specific trigger.

The trigger in Ethiopia in 2016 was the federal government's intention to implement an integrated urban master plan of Addis Ababa that encroached on the surrounding Oromia Zone. Hundreds were killed during clashes between protestors and state security 
forces. The government of Ethiopia declared a State of Emergency in October 2016 and imprisoned thousands of people without proper trial (Abbink, 2016). This sociopolitical crisis overlapped with the worst drought in half a century. Among the regions impacted by the drought were Amhara and Oromia - the regions most affected by the protests. The drought, which was triggered by the El Niño climatic phenomenon, left 10,1 million people in need of humanitarian assistance (United Nations, 2017).

In 2015 in Myanmar, violent rhetoric and clashes targeted ethnic and religious minorities, especially Muslims, including the Rohingya ethnic group. These built on the deadly inter-communal violence in Rakhine in 2012 and the passing of the discriminatory Race and Religion laws in 2015, which limit religious freedom and are discriminatory in terms of religion and gender (Farzana, 2015). Simultaneously, in 2015, Myanmar had to cope with floods and landslides triggered by an unusually heavy monsoon season and further compounded by Cyclone Komen. The cyclone made landfall on July 30, 2015, leading the government of Myanmar to list the Chin and Rakhine ethnic states among the 'natural disaster zones' on July 31, 2015 (National Natural Disaster Management Committee, 2015). In total, 125 people died, and more than 1,5 million were temporarily displaced (United Nations Office for the Coordination of Humanitarian Affairs, 2015).

In Zimbabwe, increasing political rivalries and socioeconomic decline led to protests in 2016 (triggered by the cash crisis and corruption scandals), 2018 (triggered by the contested national election results), and 2019 (triggered by the tripling of fuel prices). Particularly intense state repression was seen in 2018-2019, with the killing of dozens of people, arbitrary beatings, group punishments, and extrajudicial imprisonment (Beardsworth, Cheeseman, \& Tinhu, 2019). The 2016 El Niño phenomenon also impacted Zimbabwe, leading to the worst drought in 25 years, which left more than five million food insecure (United Nations Resident Coordinator in Zimbabwe, 2016). A state of disaster was declared on February 3, 2016, and international support was requested in 2016 (United Nations, 2016) and in November 2018 following the return of unusually dry conditions (ReliefWeb, 2018).

Ethnic politics played a role in all three cases, with minority group members, and some international aid actors, pointing towards Tigray/Bamar/Shona domination. However, it is important not to overemphasize identity and neglect socioeconomic differences (Taylor, 1982). In Myanmar's Rakhine State, and in both Ethiopia and Zimbabwe, tensions along ethnic and religious lines intermesh with the broader political economy of each context, which may, for instance, cover up (corporate) scrambles for land and resources.

In all three cases, the disaster response necessitated the interplay of state, civil society organization (CSO), and international humanitarian actors in sectors such as nutrition, housing, water, sanitation, and health.
The three cases varied widely in terms of the type of disaster (slow vs. quick onset) and multiple aspects of country context, but this is not necessarily a drawback: Particularly strong theoretical contributions can be made when "common causes or social processes can be found in spite of these contrasts" (Höglund \& Öberg, 2011, p. 117).

\section{Methods}

This article draws on one year of qualitative fieldwork conducted from February to July 2017 in Ethiopia, September 2016 to February 2017 in Myanmar, and October 2018 to May 2019 in Zimbabwe. Table 1 presents characteristics of the cases and research participants, which were selected to maximize diversity.

The small-N case study approach combines advantages of a cross-case study (analytical breadth and comparison across different contexts) with those of a single case study (in-depth contextual understanding of the examined conflict and disaster processes). The small-N case study approach aims to reach an "orderly, cumulative development of knowledge and theory" (George \& Bennett, 2005, p. 70). Drawing inspiration from the structured focused comparison approach (George \& Bennett, 2005, p. 67), we combined the rigor of (i) a common set of questions to identify contrasts and similarities across the case findings with (ii) sufficient flexibility to allow for country contextualization and increasingly focused country case designs on the basis of findings from the previous cases.

Data collection was largely standardized across the three cases, covering the same topics of disaster governance and response practices through semi-structured interviews, informal exchanges, observation, and participatory methods, following Moser and Stein (2010), when circumstances allowed. The key challenges to disaster response in authoritarian LIC contexts and the social navigation and other strategies developed by non-state actors to overcome these challenges were common to all three cases. However, the weight allocated to different issues evolved across the cases, thus analytically constructing the cases (Ragin, 1992) at different stages of the research and across the three cases. Specifically, these developments influenced the selection of countries and the increasingly detailed questions asked to better understand processes identified as key in earlier case studies. For example, the fieldwork in Myanmar and Zimbabwe, which was conducted after the fieldwork in Ethiopia, largely moved away from state perspectives to focus on non-state disaster responders' social navigation strategies.

The data were thematically analyzed in two phases, following Braun and Clarke (2006). First, contextspecificities, historical pathways, and nuances were drawn out for each case (see Desportes, 2019; Desportes, 2020; Desportes et al., 2019). Second, contrasts and similarities were sought across cases (e.g., by revisit- 
Table 1. Three cumulative country cases.

\begin{tabular}{lll}
\hline Case & Scale of focus & Numbers of research participants \\
\hline Ethiopia & National, with visits to LIC disaster areas in the & 38 community members \\
& Amhara, Oromia, and Somali regions & 22 state officials \\
& 14 CSO representatives \\
& 46 international humanitarians \\
& 2 researchers \\
Ryanmar & minority states of Chin and Rakhine & 10 community members \\
& & 1 state official \\
& 11 CSO representatives \\
& 21 international humanitarians \\
& 4 researchers \\
Cimbabwe & Community, with a focus on one peri-urban & 78 community members \\
& & 13 CSO representatives
\end{tabular}

Notes: Participant numbers refer to individual in-depth interviews, except for the counts of community members, who sometimes participated in focus groups. In the text, statements drawn from the interviews or focus group discussions are presented with information on the type of actor and date in a way that preserves all participants' confidentiality.

ing earlier cases, considering findings from later cases). This approach turns the 'comparative gesture' on its head, seeking commonalities in processes and outcomes rather than aiming to identify differences (Robinson, 2016). Seeking commonalities across diverse contexts is in line with the scenario-building exercise, which is largely conceptual and thus is "concerned as much with creating usable 'mental models' as it is with reflecting reality" (Wood \& Flinders, 2014, p. 153). Glossing over complexity and diversity to some extent and imaginatively working with ideal-typical scenarios helps to guide theoretical exploration along the core disaster response dynamics that emerge across comparable cases.

The similar authoritarian and LIC dynamics unfolding in the three cases examined here also resulted in common methodological challenges. These included trust-building and gaining access to sensitive information (e.g., reliable data on drought-induced health impacts in Ethiopia), certain areas (e.g., the Rakhine State in Myanmar), and actors (e.g., state actors in Zimbabwe). Risks to the research partners and participants, as well as associated ethical dilemmas, were also points of concern (Glasius et al., 2018; Matelski, 2014). The challenges presented by these LIC and authoritarian settings were not dissimilar to those faced by humanitarian workers: negotiating access; building trust; dealing with contradictory information and advice; navigating bureaucracy, daily encounters, and conversation topics; and selectively selfcensoring. These challenges certainly limited our inquiry and understanding, especially of the most politically sensitive issues. Nevertheless, the contradictions, rumors, and silences surrounding these issues also provided useful 'meta-data' that were considered when interpreting our findings (Fujii, 2010).

\section{Findings}

\subsection{What Is at Stake?}

The answers to the question of what is at stake may appear obvious: The state uses disaster to gain control and legitimacy, whereas some non-state actors have the opposite aim. In the interviews, it was striking that most state and powerful international aid actors framed disaster response as a wholly technical and apolitical process. In stark contrast, mutual suspicions and accusations were part of the overwhelming majority of the interviews with other types of actors.

Regarding their views of the role of the state, the participants generally agreed on the state's capacity to deal with the disaster (high in Ethiopia, low in Myanmar, mixed accounts in Zimbabwe), but they doubted the goodwill of the state. For instance, an established Zimbabwean consultant (\#1, November 29, 2018) asserted that the state did not want to see "food shortages framed as resulting from mismanagement" and aimed to showcase itself internationally as a "functioning and responsible" entity. This also applied in developmental state-minded Ethiopia and in Myanmar, which was in the midst of a 'democratic transition' in 2015. In Myanmar, an international organization (IO) representative (\#3, November 7,2018 ) said that the message the government wished to communicate to its domestic audiences was that the government mostly takes care of the majority Bamar ethnic group but not of Muslim minorities, who were portrayed as an 'internal threat' to Myanmar.

In all three countries, the state was perceived as using the disaster to advance its political goals-to end 
the protests in Ethiopia, to marginalize ethnic and religious minorities in Myanmar, and to assert the dominant party's power in Zimbabwe. This was reportedly accomplished by discriminating against already marginalized political/ethnic/religious groups in aid distributions, but also through direct violence such as the forced relocation of communities in military vehicles (as observed in Myanmar, international nongovernmental organization (INGO) representative \#17, January 22, 2018). Power plays also took place between different state bodies (e.g., different ministries aligned with competing party factions, as observed in Zimbabwe) and different governance levels (e.g., an Ethiopian district government official [\#2, December 5, 2017] criticizing how government officials at regional and federal level instrumentalized the drought for "other purposes").

Concerning non-state actors, tensions and misgivings were found in every country. In all three countries, international actors were accused of being "Western agents" with their own political agenda. The government framed CSOs as instrumentalized by the opposition party or the West in Zimbabwe. In Myanmar, aid organizations were labeled as "terrorists" because they supported the Muslim Rohingya minority, who were societally framed as terrorists (INGO \#16, January 22, 2018). This may lead to lower acceptance of these organizations or to security risks for their staff.

In Ethiopia and Myanmar especially, powerful international players were perceived as government-aligned by some of their own staff members, advocacy-oriented INGOs, and grassroots CSOs. In Zimbabwe, such criticism was voiced by community members active in the opposition party or community governance structures.

Another similarity across the three cases was the importance of history. Past 'traumatic' disaster events associated with political instrumentalization were frequently cited. In Ethiopia, the key events were the droughts in the 1970s-1980s that led to the downfall of regimes. In Myanmar, an important historical event was 2008 Cyclone Nargis, following which the governing military junta initially completely blocked all international relief. In Zimbabwe, respondents often mentioned the 2008 drought, when INGOs funded by the United States were found to support areas controlled by the opposition party. These findings highlight how institutional memory co-shapes state-aid-society relations as much as the current (geo-)political agenda, serving to 'legitimize' present fears and accusations directed toward state and non-state actors.

\subsection{What Will Happen Now: Authorities' Control}

Authorities mainly influenced the disaster response through everyday politics, including via (i) bureaucracy and (ii) information management, and by instilling a culture of (iii) uncertainty and (iv) fear. Physical attacks and roadblocks played only a limited role in constraining the disaster response. The same was true of 'bigger political acts,' although the declaration of a State of Emergency in October 2016 in Ethiopia (with associated travel bans for international actors, including diplomats), as well as state-imposed country-wide Internet and telecommunications blackouts in Ethiopia and Zimbabwe, did occur.

\subsubsection{Everyday Bureaucratic Restrictions}

In all three countries, the state controlled the 'who,' 'when,' 'where,' and 'how' of the disaster response through bureaucratic mechanisms. These included the conditions tied to the declaration of disaster emergencies and disease outbreaks (without which operations such as importing specific medicines were impossible), the granting of visas and in-country travel authorizations, and memoranda of understanding setting activity details. Organizational registration processes, such as the difficult-to-obtain Private Voluntary Organization status in Zimbabwe, also determined whether an organization could engage in disaster response, carry out advocacy, and/or receive international funding. These bureaucratic restrictions were felt most strongly in Ethiopia, where an IO staff member (\#8, August 4, 2017) referred to them as the "iron cage of bureaucracy" and in Zimbabwe, where participants mentioned "the system" by whose rules they had to play.

Powerful non-state actors such as donors and large INGOs were sometimes seen as reinforcing these restrictions. Rather than protecting CSOs against the state, INGOs were described as emphasizing the lack of capacity among CSOs and influencing CSOs' activities via guidelines and "recommendations." In Myanmar, one CSO (\#2, November 21, 2017) had been criticized by 10 representatives for being too "negative" after the CSO, which saw social justice promotion as integral to its mandate, openly accused the Myanmar government of marginalizing ethnic minorities in the response.

\subsubsection{Information Management}

In all three countries, the state controlled information flows and used this power to direct disaster responders in terms of which areas to prioritize. A Zimbabwean NGO representative (\#3, November 28,2018$)$ argued that it was not necessary for the authorities to push them out of certain areas because "the figures push you out," meaning needs data comes out of a sketchy data collection process and analysis was politically influenced. Official documents presented disaster needs assessment and analysis processes as technical multi-actor endeavors. The Zimbabwe Vulnerability Assessment Committee results, which are released by a multi-actor network, were nevertheless described as a series of "political findings" coming out of a "political body" (former employee of a donor organization now working for an INGO, \#4, June 4,2019$)$. This was also the case for district hotspot classification in Ethiopia, where the final results were reportedly set by ruling party officials in federal govern- 
ment offices. In Myanmar, needs assessment and analysis processes were not as codified, but participants noted the key role of the General Administration Department, under military stewardship, which collects information through its village tract administrator network (IO representative, \#7, January 12,2018 ).

Donors also set information management standards. Research participants noted that substantial presence 'on the ground' and trust-building were key in contexts with multilayered local LIC dynamics and interference from state actors in non-state aid processes at community level. State actors determining aid beneficiary lists reportedly occurred quite directly in Ethiopia (e.g., by ward-level government officials) and indirectly in Zimbabwe (e.g., non-state aid actors being pushed to operate via 'government-preferred' community extension workers). However, direct engagement between communities and non-state disaster responders as well as independent data collection were constrained by a lack of earmarked funding. INGO representatives in Ethiopia (e.g., \#44, May 25, 2017) and Zimbabwe (\#5, January 31, 2019) and the Zimbabwean former employee of a donor organization (\#4, June 4, 2019) indicated that donors themselves considered only figures from the Ethiopian district assessment/Zimbabwe Vulnerability Assessment Committee to be legitimate. By further establishing the authority of information that is largely viewed as politically distorted, donors thus prevent the collection of more accurate information to guide area and beneficiary selection.

\subsubsection{Uncertainty}

Uncertainty derived from the ambiguity and uneven application of guidelines. In the examined cases, the disaster response operations were officially managed by civil servants, but political parties or deep state bodies (e.g., the dominant party politburo in Ethiopia and Zimbabwe and the General Administration Department in Myanmar) influenced them behind the scenes. The declaration of a state of disaster was deemed belated and politically motivated in Ethiopia and Zimbabwe. In Myanmar, withholding initially promised authorizations for aid to non-Muslim communities was interpreted as bureaucratically disguised political manipulation by IO (\#3, November 7, 2017) and donor (\#4, February 1, 2018) staff members.

Policy instruments can also propagate uncertainty. In Ethiopia, the 70/30 regulation limited administrative spending to a maximum of $30 \%$ without clearly defining this type of spending, thus leaving open the possibility of shutting down an organization for violating this regulation. In Myanmar and Zimbabwe, actors could be charged under the 2013 Telecommunications Law and the 2002 Public Order and Security Act (amended in 2007), respectively, if their actions were judged as threatening 'national security' (embassy official posted in Myanmar, \#1, October 6, 2017; embassy offi- cial, \#1, November 9, 2018; 10, \#7, January 28, 2018, in Zimbabwe).

\subsubsection{Fear}

The above restrictions and uncertainty are particularly effective when non-state disaster responders feel monitored and when there are repercussions for transgressions. Concerning monitoring, formally registered nongovernmental organizations (NGOs) had to submit organizational budgets and plans to state authorities in all three countries. In all three countries, major IOs were also reported to have been "infiltrated" by state actors.

International aid actors faced the threat of expulsion from each of the examined countries. In addition, INGO and NGO directors could be held personally liable for 'administrative faults,' and CSO representatives experienced verbal or physical intimidation for carrying out what they saw as their humanitarian mandate. In Ethiopia, a CSO driver (\#25, May 5, 2017) was physically struck by a government official while assisting a woman who had been wounded in the protests. In Myanmar, an INGO representative (\#16, January 22, 2018) had his identification card, including his photograph, printed in a state newspaper article covering how his organization supported the "illegal and dangerous Rohingya." In Zimbabwe, a CSO representative (\#8, November 29, 2018) was interrogated and intimidated by the Central Intelligence Organization for distributing food aid without the required organizational status.

\subsection{What Will Happen Now: Actions of Non-authorities}

Operating in these contexts of state control, civil society and international disaster responders relied on different strategies that can be categorized, from the least confrontational to the most confrontational: as (i) complying within the system; (ii) trying to beat the system from within; and (iii) resisting.

\subsubsection{Compliance}

'Confrontation does not work here' was a common mantra across the three cases. A frequently used strategy was self-censorship, which was observed in words, action, and projection of knowledge (i.e., purposively displaying ignorance regarding certain issues). Even highly advocacy-oriented organizations remained silent. An INGO official in Myanmar (\#17, January 22, 2018) stated, "Our organization is usually a loud organization...but here we never participate in a shout." An exception to this general finding was Myanmar's peripheral Chin State, where the central government's grasp was weaker and vocal CSO representatives knew when and how to lobby and advocate for support for their communities' plight.

Aid actors strategically reinterpreted their mandates and humanitarian principles. For instance, neutrality was 
reinterpreted as staying out of conflict zones altogether (Ethiopia), and impartiality was taken to mean not privileging one religious group over the other even when their needs differed (Myanmar). In interactions with state officials in Zimbabwe, 10 and CSO representatives pretended not to notice that food aid beneficiaries were selected on the basis of party affiliation, linking the issue to targeting inefficiencies instead.

\subsubsection{Social Navigation}

Actors navigated the aforementioned challenges in four main ways, with some non-state actors aiming to beat the state on its own terrain, namely that of everyday politics.

A main feature of the state system is its technicality and overreliance on (bureaucratic) guidelines to control humanitarian operations. In the first navigation strategy, disaster responders tried to use this to their advantage and displayed technical discourses and artefacts to reach specific goals. In Ethiopia, an INGO director (\#44, May 25, 2017) told government officials that his organization had to conduct independent monitoring visits because of donor guidelines outside his control. In Myanmar, a CSO (\#2, November 21, 2017) drafted purposefully intricate reports full of graphs and footnotes to lobby UN officials. In Zimbabwe, an IO official (\#5, February 22, 2019) stated that the politicization of food aid could be raised based on solid data grounding.

Second, disaster responders were careful in addressing sensitive issues such as the root causes of disaster (e.g., the Zimbabwean land reform and its impact on food production), politicization of the disaster response (e.g., the Myanmar state marginalizing minorities), and even disaster impacts (e.g., cholera epidemics in 21st century Ethiopia boasting developmental and economic successes such as 'double-digit growth'). Certain issues were downplayed; for instance, cholera was referred to as 'acute watery diarrhea' in Ethiopia, and affiliations with Western sanction-imposing donor countries were hidden in Zimbabwe. In Myanmar's Rakhine State, perception monitoring and visibility guidelines (e.g., concerning the fore-or backgrounding of certain activities, organizational logo or pictures on which staff members could be identified) were crucial, both online and in the field. In all three cases, actors highlighted their apolitical nature and carefully screened the religion, ethnicity, or language skills of their staff members to ensure their strategic fit as interlocutors, from local to national level.

Third, disaster responders strategically (un-)made actor relations. Partnering with CSOs is useful in LIC contexts, improving knowledge of and acceptance by communities. CSOs and national staff members of international bodies were considered skilled negotiators with authorities. However, CSOs were also societally positioned and potentially biased themselves, leading some international participants to dismiss a 'localized' disaster response in these LIC contexts. From a CSO perspective, bonds with powerful actors, whether they were locally established public servants or strategically placed IO officials, were described as beneficial. Multi-mandate INGOs and NGOs could develop broad (policy-making) networks and fall back on these during disaster crisis moments.

The fourth navigation strategy was observed only in Myanmar, where some CSOs and international actors departed from the principle of impartiality in their targeting by distributing aid equally to neighboring communities regardless of actual need. They argued that this approach limited tensions between Muslim and Buddhist communities in Rakhine State and between different Chin ethnic groups in Chin State.

\subsubsection{Resistance}

In the three cases, resisting the system took five main forms, although resistance was uncommon and rarely openly confrontational.

One strategy was bypassing the system via parallel routes. Of all the actors in the three case studies, only Chin State CSOs managed to source and distribute relief via parallel minority networks. To accomplish this, they relied on ethnic and/or Christian ties with other CSOs and communities (e.g., in the Myanmar ethnic state of Kachin or the Mizoram region in India), as well as international networks.

Disaster response challenges could also be raised directly in high-level, non-public situations, such as in UN offices in New York (IO staff member in Ethiopia, \#9, May 30, 2017), or at field level with trusted government officials.

Additionally, isolated statements indicated that some actors operated 'under the radar.' The few examples of this concerned organizations working without formal authorization, as reported in Myanmar (INGO, \#11, January 10, 2018) and directly shared by the organization in question in Zimbabwe (CSO, \#8, November 29, 2018). In Ethiopia, one INGO representative (\#32, May 28, 2017) confessed to sending "fake patients" to clinics to assess the spread of an epidemic in drought areas where the government had restricted access.

More rarely, non-state disaster responders chose to boycott specific processes or to leave the country. Of the 41 INGO agencies represented in this study, only one in Myanmar reported discussing these possibilities on a weekly basis, and one had decided to leave Ethiopia. The latter INGO (further details withheld to ensure confidentiality) decided to leave the country without issuing a press statement denouncing how the country constraints did not allow them to carry out their humanitarian mandate following discussion with fellow INGOs, who feared repercussions.

Only one INGO, in Zimbabwe, openly denounced the politicization of food aid during the 2016 drought response. A representative from this INGO noted that this was possible because of the organization's established presence in Zimbabwe and recognized status within various (government) committees. 


\section{Conclusions}

The authoritarian LIC cases of Ethiopia, Myanmar, and Zimbabwe differed widely; nevertheless, there were strong similarities in the research participants' perceptions of what was at stake and of how the disaster response was shaped. This highlights the usefulness of the small-N scenario-based approach in identifying finegrained disaster-conflict patterns.

These patterns were identified in exploring the questions of what is at stake and what happens now, differentiating the latter for different types of actors with varying interests and power. This approach allowed us to capture the role of authorities and 'big political acts' revolving around the distribution of values and responsibilities, which Olson (2000) marked as crucial. The approach also directed our attention toward non-authorities, the interplay between actors, and everyday politics.

Based on fieldwork in three countries, we identified patterns in how authorities and non-authorities strategize to advance their stakes in the response, as presented in Table 2. In all three countries, non-state disaster responders' actions were hampered by clear restrictions, but they were especially obstructed by everyday bureaucratic acts that constrained access in more duplicitous ways and by a culture of uncertainty and fear. These political obstructions are closely related to actors' images of each other, picturing the other as 'dangerous' in an already unstable LIC context. Caught in this situation, the overwhelming majority of non-state disaster responders - even those with a tradition of open dissent-opted for a non-confrontational approach. This resulted in a problematic homogenization of disaster response practices, where accountability is first toward authorities and where power imbalances are strengthened.

Table 2. Actor strategies to advance their stake in disaster response.

\begin{tabular}{ll}
\hline Authorities & Non-authorities \\
\hline Bureaucratic restrictions & Compliance \\
Monopolizing data & Social navigation \\
Instilling uncertainty & Limited resistance \\
Instilling fear & \\
\hline
\end{tabular}

Our findings speak to the disaster governance literature in three major ways.

First, our findings highlight how social institutions, such as power constellations, discourses, governance arrangements, and codified practices, act as key transmission belts between LIC and disaster response dynamics Institutional memory of political instrumentalization of aid, divisive LIC discourses, and a culture of distrust translate into accusations, and strong and opaque government structures produce restrictive and uncertain regulations. Heavy-handed deep state bodies also exert influence on the humanitarian arena. Our findings thus support the 'disaster as lens' approach, which sees disasters as revealing rather than disrupting social processes and inequities (Cuny, 1983; Venugopal \& Yasir, 2017). These findings also point toward the links between the big political framings and histories and everyday disaster response acts in conflict settings. The answers to the questions of what is at stake (rather focusing on macropolitical dynamics) and what happens now (focusing on micro-political dynamics) are intimately interlinked. In addition to the need to study macro-political (Olson, 2000) and micro-political disaster dynamics (Peters et al., 2019; Siddiqi, 2018), further research on these links would be beneficial.

Second, the importance of framing practices for disaster response cannot be overestimated. The concept of the humanitarian arena (Hilhorst \& Jansen, 2010) sets out disaster response as the outcome of interactions. Our study highlights the discursive aspects of these interactions. In LIC scenarios, state, societal, and international disaster responders are not only occupied with the technicalities and governance of the actual responsefrom information gathering to aid distribution-but also with the governance of how the response is perceived in political contexts from local to international levels. Ethical questions are raised when 'gaining acceptance' takes precedence over acting in accordance with humanitarian principles.

Third, our findings should serve to remind researchers to remain open-minded concerning the different actors' roles, rather than focusing only on the authoritarian properties of the state. Humanitarian actors can also be powerful 'authorities.' Studies of aid dynamics in authoritarian settings should thus also detail how non-state actors co-shape the 'rules of the game,' especially in the crucial area of information management.

Although this article has focused on the workings of governance, how this plays out in the lives of disasteraffected people remains a pertinent question. Assisting affected communities will obviously have secondary (or even primary) political objectives. Powerful actors set the rules of disaster governance, and, in authoritarian settings, disaster responders tend to bend toward the state. Our study has highlighted how less powerful actors navigate the dominant power relations via everyday politics but, in most cases, end up being played by the system rather than playing it. The strong nature of authoritarian states may make disaster response effective and efficient, but it can also worsen the situation for affected communities. As Olson stated (2000, p. 266), “ignoring the explicit political dimension of disasters...does not make it go away."

\section{Acknowledgments}

This research was financed by the NWO, the Netherlands Organisation for Scientific Research, $\mathrm{VICl}$ grant 
no. $453 / 14 / 013$. We greatly thank all research participants and assistants for their time and insights.

\section{Conflict of Interests}

The authors declare no conflict of interests.

\section{References}

Abbink, J. (2016). Stable instability: Renewed turmoil in Ethiopia (part 1). Standplaats Wereld. Retrieved from http://standplaatswereld.nl/renewed-turmoilin-ethiopia-part-2

Azar, E. (1990). The management of protracted social conflict: Theory and cases. Hampshire: Darmouth.

Beardsworth, N., Cheeseman, N., \& Tinhu, S. (2019). Zimbabwe: The coup that never was, and the election that could have been. African Affairs, 118(472), 1-17.

Blaikie, P. M., Cannon, T., Davis, I., \& Wisner, B. (Eds.). (1994). At risk: Natural hazards, people's vulnerability, and disasters. New York, NY: Routledge.

Braun, V., \& Clarke, V. (2006). Using thematic analysis in psychology. Qualitative Research in Psychology, 3(2), 77-101.

Carrigan, A. (2015). Towards a postcolonial disaster studies. In E. DeLoughery, J. Didur, \& A. Carrigan (Eds.), Global ecologies and the environmental humanities: Postcolonial approaches (1st ed., pp. 117-139). Abingdon: Routledge.

Cunningham, A. J. (2018). International humanitarian NGOs and state relations: Politics, principles, and identity. Abingdon and New York, NY: Routledge.

Cuny, F. C. (1983). Disasters and development. Oxford: Oxford University Press.

de Billon, P. L., \& Waizenegger, A. (2007). Peace in the wake of disaster? Secessionist conflicts and the 2004 Indian Ocean tsunami. Transactions of the Institute of British Geographers, 32(3), 411-427.

del Valle, H., \& Healy, S. (2013). Humanitarian agencies and authoritarian states: A symbiotic relationship? Disasters, 37, S188-S201.

Demmers, J. (2012). Theories of violent conflict: An introduction. New York, NY: Routledge.

Desportes, I. (2019). Getting relief to marginalised minorities: The response to cyclone Komen in 2015 in Myanmar. Journal of International Humanitarian Action, 4(1), 39-59.

Desportes, I. (2020). Repression without Resistance: Disaster Responses in Authoritarian Low-Intensity Conflict Settings (Doctoral dissertation). International Institute of Social Studies, Erasmus University, The Hague, The Netherlands.

Desportes, I., Mandefro, H., \& Hilhorst, D. (2019). The humanitarian theatre: Drought response during Ethiopia's low-intensity conflict of 2016. Journal of Modern African Studies, 57(1), 1-29.

Drury, A. C., \& Olson, R. S. (1998). Disasters and political unrest: An empirical investigation. Journal of Contin- gencies and Crisis Management, 6(3), 153-161.

Farzana, K. F. (2015). Boundaries in shaping the Rohingya identity and the shifting context of borderland politics. Studies in Ethnicity and Nationalism, 15(2), 292-314.

Fujii, L. A. (2010). Shades of truth and lies: Interpreting testimonies of war and violence. Journal of Peace Research, 47(2), 231-241.

Galtung, J. (1996). Peace by peaceful means: Peace and conflict, development and civilization. Thousand Oaks, CA: International Peace Research Institute and Sage.

George, A. L., \& Bennett, A. (2005). Case studies and theory development in the social sciences. Cambridge, MA: MIT Press.

Giddens, A. (1984). The constitution of society: Outline of the theory of structuration. Berkeley, CA, and Los Angeles, CA: University of California Press.

Glasius, M. (2018). What authoritarianism is...and is not: A practice perspective. International Affairs, 94(3), 515-533.

Glasius, M., de Lange, M., Bartman, J., Dalmasso, E., Lv, A., Del Sordi, A., . . Ruijgrok, K. (2018). Research, ethics and risk in the authoritarian field. London: Palgrave Macmillan.

Harvey, P. (2013). International humanitarian actors and governments in areas of conflict: Challenges, obligations, and opportunities. Disasters, 37, S151-S170.

Heidelberg Institute for International Conflict Research. (2019). Conflict barometer 2018. Heidelberg: Heidelberg Insitute for International Conflict Research. Retrieved from http://www.hiik.de/?lang=en

Hewitt, K. (Ed.) (1983). Interpretations of calamity from the viewpoint of human ecology. London: George Allen \& Unwin.

Hilhorst, D. (Ed.). (2013). Disaster, conflict and society in crises: Everyday politics of crisis response. New York, NY: Routledge.

Hilhorst, D., \& Jansen, B. (2010). Humanitarian space as arena: A perspective on the everyday politics of aid. Development and Change, 41(6), 1117-1139.

Hilhorst, D., van Voorst, R., Mena, R. A., Desportes, I., \& Melis, S. (2019). Disaster response and humanitarian aid in different conflict scenarios. Geneva: United Nations International Strategy for Disaster Reduction.

Höglund, K., \& Öberg, M. (2011). Understanding peace research: Methods and challenges. London and New York, NY: Routledge.

Human Security Report Project. (2016). Human security report project: Our work. human security report group. Geneva: United Nations International Strategy for Disaster Reduction. Retrieved from http:// www.hsrgroup.org/our-work/overview.aspx

Hutchison, E. (2014). A global politics of pity? Disaster imagery and the emotional construction of solidarity after the 2004 Asian tsunami. International Political Sociology, 8(1), 1-19. 
Jacobs, J. (2012). Commentary: Comparing comparative urbanisms. Urban Geography, 33(6), 904-914.

Markakis, J. (2011). Ethiopia: The last two frontiers. Oxford: James Currey.

Matelski, M. (2014). On sensitivity and secrecy: How foreign researchers and their local contacts in Myanmar deal with risk under authoritarian rule. Journal of Burma Studies, 18(1), 59-82.

Matelski, M. (2016). Constructing civil society in Myanmar: Struggles for local change and global recognition (Unpublished Doctoral dissertation). Vrije University of Amsterdam, Amsterdam, The Netherlands.

McGregor, J. (2013). Surveillance and the city: Patronage, power-sharing and the politics of urban control in Zimbabwe. Journal of Southern African Studies, 39(4), 783-805.

Moser, C. O. N., \& Stein, A. (2010). Implementing urban participatory climate change adaptation appraisals: A methodological guideline. Manchester: Global Urban Research Centre, University of Manchester.

National Natural Disaster Management Committee. (2015). Situation report No. 3: National natural disaster management committee (Report No. 3). Nay Pyi Daw: National Natural Disaster Management Committee.

Nel, P., \& Righarts, M. (2008). Natural disasters and the risk of violent civil conflict. International Studies Quarterly, 52(1), 159-185.

O'Keefe, O., Westgate, K., \& Wisner, B. (1976). Taking the naturalness out of natural disaster. Nature, 260, 566-567.

Olson, R. S. (2000). Toward a politics of disaster: Losses, values, agendas, and blame. International Journal of Mass Emergencies and Disasters, 18(2), 265-288.

Pelling, M., \& Dill, K. (2006). Natural disasters' as catalysts of political action (ISP/NSC Briefing Paper 06/01). London: Chatham House.

Pelling, M., \& Dill, K. (2010). Disaster politics: Tipping points for change in the adaptation of sociopolitical regimes. Progress in Human Geography, 34(1), 21-37.

Peters, K., Holloway, K., \& Peters, L. E. (2019). Disaster risk reduction in conflict contexts (Working Paper No. 556). London: Overseas Development Institute.

Ragin, C. (1992). Introduction: Cases of 'what is a case'?' In C. Ragin \& H. Becker (Eds.), What is a case? Exploring the foundations of social inquiry (pp. 1-17). Cambridge: Cambridge University Press.

ReliefWeb (2018). Southern Africa: Drought-Nov 2018. ReliefWeb. Retrieved from https://reliefweb.int/ disaster/dr-2018-000429-zwe

Robinson, J. (2016). Comparative urbanism: New geogra- phies and cultures of theorizing the urban. International Journal of Urban and Regional Research, 40(1), 187-199.

Siddiqi, A. (2018). Disasters in conflict areas: Finding the politics. Disasters, 42(S2), S161-S172.

Taylor, R. H. (1982). Perceptions of ethnicity in the politics of burma. Southeast Asian Journal of Social Science, 10(1), 7-22.

United Nations. (2016). Zimbabwe humanitarian response plan 2016. United Nations Office for the Coordination of Humanitarian Affairs. Retrieved from https://www.humanitarianresponse.info/en/ operations/zimbabwe/document/zimbabwehumanitarian-response-plan-2016

United Nations. (2017). As new drought hits Ethiopia, UN urges support for Government's 'remarkable' efforts. UN News. Retrieved https://news.un.org/en/ story/2017/01/550402-new-drought-hits-ethiopiaun-urges-support-governments-remarkable-efforts

United Nations International Strategy for Disaster Reduction. (2015). Sendai framework for disaster risk reduction 2015-2030. New York, NY: United Nations Office for Disaster Risk Reduction. Retrieved from https:// www.unisdr.org/we/inform/publications/43291

United Nations Office for the Coordination of Humanitarian Affairs. (2015). Myanmar floods and landslides 2015. ReliefWeb. Retrieved from https://reliefweb. int/disaster/fl-2015-000080-mmr

United Nations Resident Coordinator in Zimbabwe. (2016). Effects of drought linger in rural areas, aggravate urban vulnerability: Zimbabwe. ReliefWeb. Retrieved from https://reliefweb.int/report/ zimbabwe/effects-drought-linger-rural-areasaggravate-urban-vulnerability

Venugopal, R., \& Yasir, S. (2017). The politics of natural disasters in protracted conflict: The 2014 flood in Kashmir. Oxford Development Studies, 45(4), 424-442.

Vigh, H. (2009). Motion squared: A second look at the concept of social navigation. Anthropological Theory, 9(4), 419-438.

Wisner, B. (2012). Violent conflict, natural hazards and disaster. In The Routledge handbook of hazards and disaster risk reduction (pp. 65-76). London and New York, NY: Routledge.

Wisner, B., Blaikie, P., Cannon, T., \& Davis, I. (2003). At risk: Natural hazards, people's vulnerability and disasters. London and New York, NY: Routledge.

Wood, M., \& Flinders, M. (2014). Rethinking depoliticisation: Beyond the governmental. Policy \& Politics, 42(2), 151-170. 


\section{COGITATIO}

\section{About the Authors}

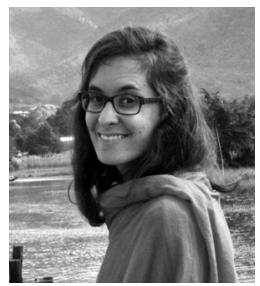

Isabelle Desportes is a Geographer by training and PhD Researcher at the International Institute for Social Studies (ISS) of Erasmus University in The Hague. Within the 'When disaster meets conflict' research programme, she focuses on the politics of disaster response in authoritarian lowintensity conflict settings. Prior to her $\mathrm{PhD}$, she has worked on climate change and disaster governance for international organizations, local municipality, and civil society organizations. For more details: https://www.eur.nl/en/people/i-desportes

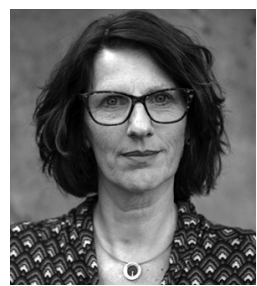

Dorothea Hilhorst is a Professor of humanitarian studies at the International Institute for Social Studies (ISS) of Erasmus University in The Hague. Her focus is on aid-society relations: studying how aid is embedded in the context. She has a special interest in the intersections of humanitarianism with development, peacebuilding and gender-relations. Currently, her main research programme concerns cases where 'disasters meets conflict,' that studies disaster governance in high-conflict, low-conflict and post-conflict societies. For more details: https://dorotheahilhorst.nl 